\title{
Effects of crevice size on the establishment of macroalgae in subtropical streams
}

\author{
Tonetto, $A F^{a *}{ }^{*}$, Peres, $C K .^{b}$, Khnayfes, $M A .^{a}$ and Branco, CCZ. ${ }^{a}$ \\ ${ }^{a}$ Laboratory of Aquatic Biology, Department of Biological Sciences, São Paulo State University - UNESP. \\ Av. Dom Antônio, 2100, CEP 19806-900, Assis, SP, Brazil \\ bUniversidade Federal da Integração Latino-Americana - UNILA, Av. Tancredo Neves, 6731, \\ Parque Tecnológico Itaipu, CEP 85867-970, Foz do Iguaçu, PR, Brazil \\ *e-mail: aureliofajar@hotmail.com
}

Received: March 19, 2013 - Accepted: June 10, 2013 - Distributed: December 31, 2014

(With 3 Figures)

\begin{abstract}
Considering that in previous studies, the surface roughness (micrometric dimension) showed a weak effect on the colonization of stream macroalgae, we investigated the effects of different crevice sizes (milimetric dimension, a scale slightly higher than previous investigations) on the macroalgal abundance in three streams exposed to full sunlight in southern Brazil. We used smooth sterile glass plates with different shapes: $\mathrm{P}$ - plane surface without crevices; $\mathrm{S}-$ sinuous surface (depth of crevices with $0.159 \mathrm{~mm} \pm 0.03) ; \mathrm{N}$ - non-unifom surface $(0.498 \mathrm{~mm} \pm 0.09)$; $\mathrm{C}-$ surfaces with convex structures $(1.190 \mathrm{~mm} \pm 0.12)$; and three additional surface types with different patterns of heterogeneity with combinations of glass pieces: $\mathrm{P}+\mathrm{S}(\mathrm{H} 1) ; \mathrm{P}+\mathrm{S}+\mathrm{N}(\mathrm{H} 2)$ and $\mathrm{P}+\mathrm{S}+\mathrm{N}+\mathrm{C}(\mathrm{H} 3)$. The plates were placed into the streams and after 105 days the percent cover of macroalgal community was measured. No significant differences among treatments were recorded. However, we observed a trend of macroalgae occurs within the crevices in all treatments and this suggests that, for stream macroalgae, the crevice sizes used in this study was still not enough to provide an expressive algal growth, even in the treatment with bigger crevices.
\end{abstract}

Keywords: habitat structure, surface shape, artificial substrate, refugia, stream macroalgae.

\section{Efeitos do tamanho de fendas no estabelecimento de macroalgas em riachos subtropicais}

\section{Resumo}

Considerando que em estudos anteriores a rugosidade da superfície (dimensão micrométrica) mostrou um fraco efeito sobre a colonização de macroalgas lóticas, nós investigamos os efeitos de tamanhos diferentes (em dimensões milimétricas, uma escala ligeiramente maior do que as investigações anteriores) sobre a abundância de macroalgas em três riachos expostos a pleno sol no sul do Brasil. Utilizamos placas lisas de vidro estéreis com formas diferentes: $\mathrm{P}$ - superficie plana sem fendas; $\mathrm{S}$ - superfície sinuosa (profundidade de fendas com $0.159 \mathrm{~mm} \pm 0.03$ ), $\mathrm{N}$ - superfície não-unifome $(0.498 \mathrm{~mm} \pm 0.09), \mathrm{C}$ - superficie com estruturas convexas $(1.190 \mathrm{~mm} \pm 0.12)$, e três tipos de superfície adicionais com diferentes padrões de heterogeneidade construídas apartir da combinação de peças de vidro: $\mathrm{P}+\mathrm{S}(\mathrm{H} 1)$, $\mathrm{P}+\mathrm{S}+\mathrm{N}(\mathrm{H} 2)$ e $\mathrm{P}+\mathrm{S}+\mathrm{N}+\mathrm{C}(\mathrm{H} 3)$. As placas foram instaladas nos riachos e após 105 dias a cobertura percentual da comunidade de macroalgas foi medida. Não houve diferenças significativas entre os tratamentos. Porém, observamos uma tendência das macroalgas ocorrerem dentro das fendas em todos os tratamentos e, isso sugere que, para macroalgas lóticas, os tamanhos das fendas utilizadas neste estudo ainda não foram suficientes para proporcionar um expressivo crescimento de algas, mesmo no tratamento com fendas maiores.

Palavras-chave: estrutura do hábitat, forma da superfície, substrato artificial, refúgios, macroalgas de riachos.

\section{Introduction}

Lotic systems comprise habitats with enough complexity to provide a heterogeneous environment (Poff and Ward, 1990; Townsend and Hildrew, 1994). This environment can be characterized by specific environmental factors (e.g., light, nutrients, velocity, temperature and substrate type) which are important for the occurrence and distribution of benthic algae in streams (Sheath et al., 1989; Everitt and Burkholder, 1991; Rosemond and Brawley, 1996). For lotic macroalgae (sensu Sheath and Cole, 1992), recent studies have suggested that variations in the environment 
in small scale would represent the most important factor for their presence, and each variation would be determined by combinations of specific factors in microhabitat scale (Krupek et al., 2008; Branco et al., 2009; Peres et al., 2009).

The substrate surface is an important element of the microhabitat complexity and it can be viewed on different aspects, including texture (micrometric dimension) and presence and size of crevices (milimetric dimension). The substrate texture has been related with establishment of benthic algae in both lotic and lentic environment (Bergey and Weaver, 2004; Scardino et al., 2006; Murdock and Dodds, 2007), and the accumulation of microalgae has been reported as higher in rough surfaces due to increase in sedimentation (Johnson, 1994), cellular adherence (Scardino et al., 2006), and protection from abrasive disturbances of water flow and herbivory (Dudley and D'Antonio, 1991; Bergey and Weaver, 2004). However, the majority of these works were done in very small dimensions. For example, Scardino et al. (2006) found that roughness ranging from 1-14 mm increases the cell fixation while Murdock and Dodds (2007) reported a gain of algal biomass until a peak of $17 \mathrm{~mm}$ of roughness.

Similar studies for stream macroalgae are very scarce and the influence of substrate texture was not completely clarified for these organisms. Dudley and D'Antonio (1991) found that the establishment of macroalgae differed in relation to texture (smooth vs rough) surface. However, the authors commented that both surfaces used in the experiment were delicately rough and larger differences in colonization were not found. The same situation may have occurred to Branco et al. (2010), wherein the authors commented that the low influence of the types of substrates may have been affected by mucilaginous matrix (formed by diatoms in the early stages of colonization) which masked the differences in the texture of the substrates.

Nevertheless, investigating crevices size as refugia for diatoms, Bergey (1999) found that larger crevices had a better protection for larger algae. As macroalgae have a greater size and no experimental investigation focusing on influence of crevice size on development of this algal community was yet conducted, we carried out the present study to investigate the colonization and the establishment of macroalgal community on surfaces with milimetric crevices, a scale slightly higher than previous investigations. Yet, we combined pieces of these surfaces to create a heterogeneous substrate, aiming an approximation of natural stream stones, in which occurs crevices with different sizes in the same surface. In general, we expected that surfaces with higher crevice sizes would provide a better growth of macroalgae.

\section{Material and Methods}

The study was conducted in three stream segments located at the Pedras River Basin, which is between $25^{\circ} 13^{\prime} 10^{\prime \prime} \mathrm{S}$ and $25^{\circ} 26^{\prime} 24^{\prime \prime} \mathrm{S} ; 5^{\circ} 13^{\prime} 10^{\prime \prime} \mathrm{W}$ and $51^{\circ} 28^{\prime} 40^{\prime}$ ' $\mathrm{W}$, in Paraná State, southern Brazil. The stream segments were similar in their environmental characteristics: the light intensity reaching the water column was $100 \%$ of the available light $\left(\sim 2300 \mathrm{mmol} . \mathrm{m}^{-2} \mathrm{~s}^{-1}\right)$; depth was enough to guarantee total sampler submersion during the entire experimental period; and the natural substratum was composed predominantly by boulders and cobbles $(\sim 90 \%)$. In a previous study (Krupek et al., 2007$)$ of the stream beds, the presence of macroalgal species pertaining to Chlorophyta, Cyanobacteria and Rhodophyta phyla on natural substrates was noted. The macroalgae were characterized according to the definition of Sheath and Cole (1992), which is represented by a specimen recognized by naked eye.

The artificial substrates used for the experiment were sterile glass plates $\left(10 \mathrm{~cm} \times 10 \mathrm{~cm}=100 \mathrm{~cm}^{2}\right)$ (Branco et al., 2010). We used four types of glass plates as following: $\mathrm{P}$ - plane surface without crevices (Control); $\mathrm{S}-$ sinuous surface (crevices with $0.149 \mathrm{~mm} \pm 0.03$ of depth); $\mathrm{N}$ - non-uniform surface (with $0.498 \mathrm{~mm} \pm 0.09$ ); $\mathrm{C}$ - surfaces with convex structures (with $1.19 \mathrm{~mm} \pm 0.12$ ). In addition to these homogeneous plates (i.e., homogenous treatments), we constructed other three combined types of plates with different patterns of heterogeneity, aiming an approximation of natural rocks. These heterogeneous plates (i.e., heterogeneous treatments) were composed by particular combinations of small pieces of the homogeneous plates $(5 \mathrm{~cm} \times 1 \mathrm{~cm})$, as follows: $\mathrm{H} 1-\mathrm{P}+\mathrm{S}, \mathrm{H} 2-\mathrm{P}+\mathrm{S}$ $+\mathrm{N}$, and $\mathrm{H} 3-\mathrm{P}+\mathrm{S}+\mathrm{N}+\mathrm{C}$.

The glass pieces of heterogeneous treatments were randomly bonded to each other in order to cover the same surface area observed on homogeneous treatments. However, heterogeneous treatments had, additionally, larges grooves $(0.75 \pm 0.3 \mathrm{~mm}$ in width, $2.87 \pm 0.46 \mathrm{~mm}$ in depth), as a result of the junction of the homogeneous glass pieces. The physical structure of all surfaces in three scales is illustrated in Figure 1. To guarantee that each type of surface shapes represents a distinguished pattern of spatial structure we realize an ANOVA analysis and the results showed that all surfaces were different each other in the size of crevices ( $\mathrm{F}=970.2$ and $p<0.001)$.

A set of seven plates, one for each treatment, was attached to a concrete plate of $1 \mathrm{~m}^{2}(\sim 20 \mathrm{~kg})$, forming a block in a randomized block design. Within each block, the treatments were randomly placed. The concrete plates were used to avoid samplers drifting and guarantee their complete submersion throughout experimental period. In field, the blocks were installed in riffle areas of each stream, totaling three replicated blocks.

The experiment was conducted entirely during the fall-winter seasons, the most favorable period for the development of macroalgal communities in the study region (Branco et al., 2009). The blocks were installed in April 2009 and remained in the streams for 105 days. This experimental period was enough to guarantee effective colonization and, on the other hand, to avoid marked seasonal variations in the environmental conditions (Branco et al., 2010). Blocks were checked weekly during the experimental period for cleaning and maintenance for remove eventual pieces of leaves and twigs stuck in the samplers. 

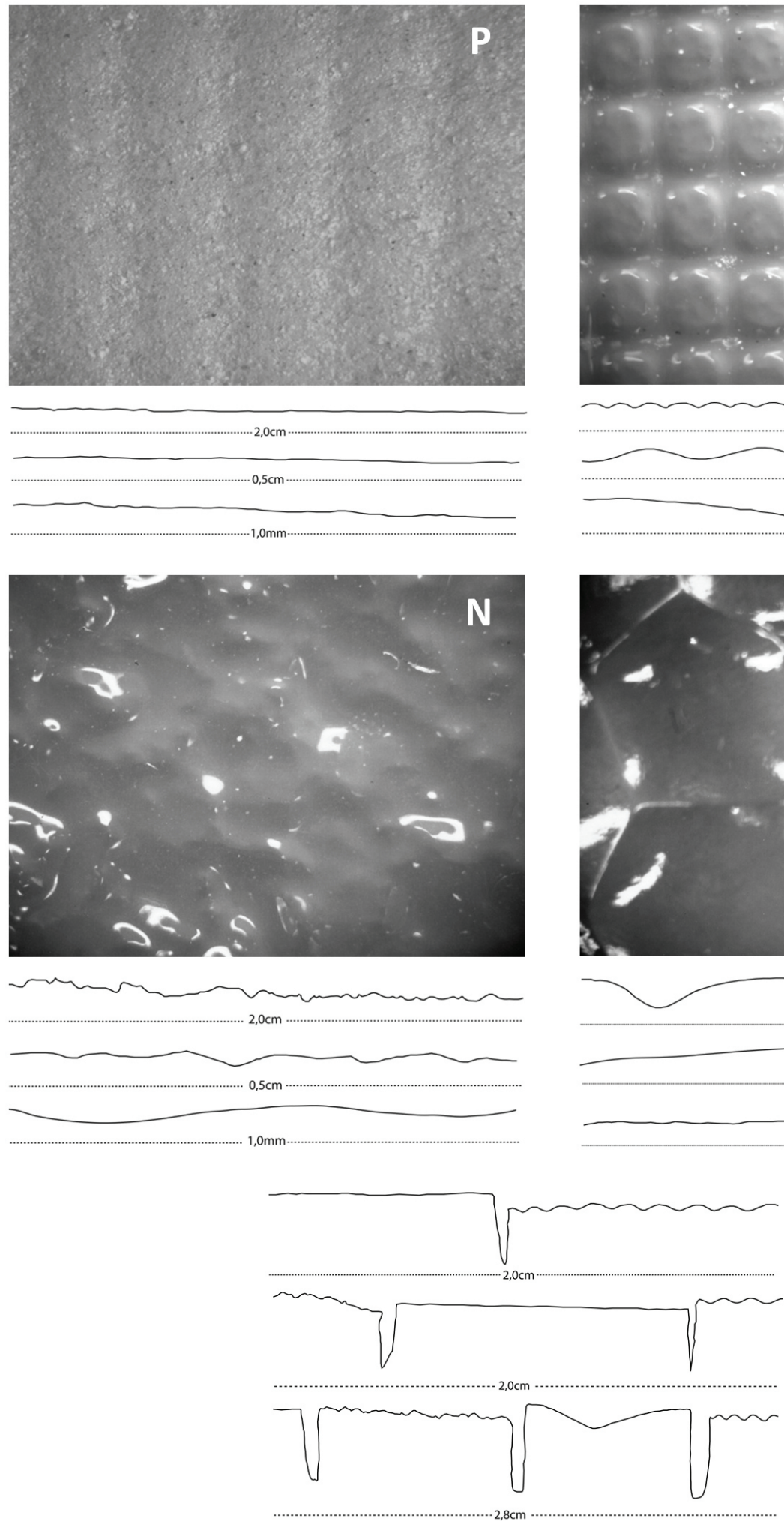
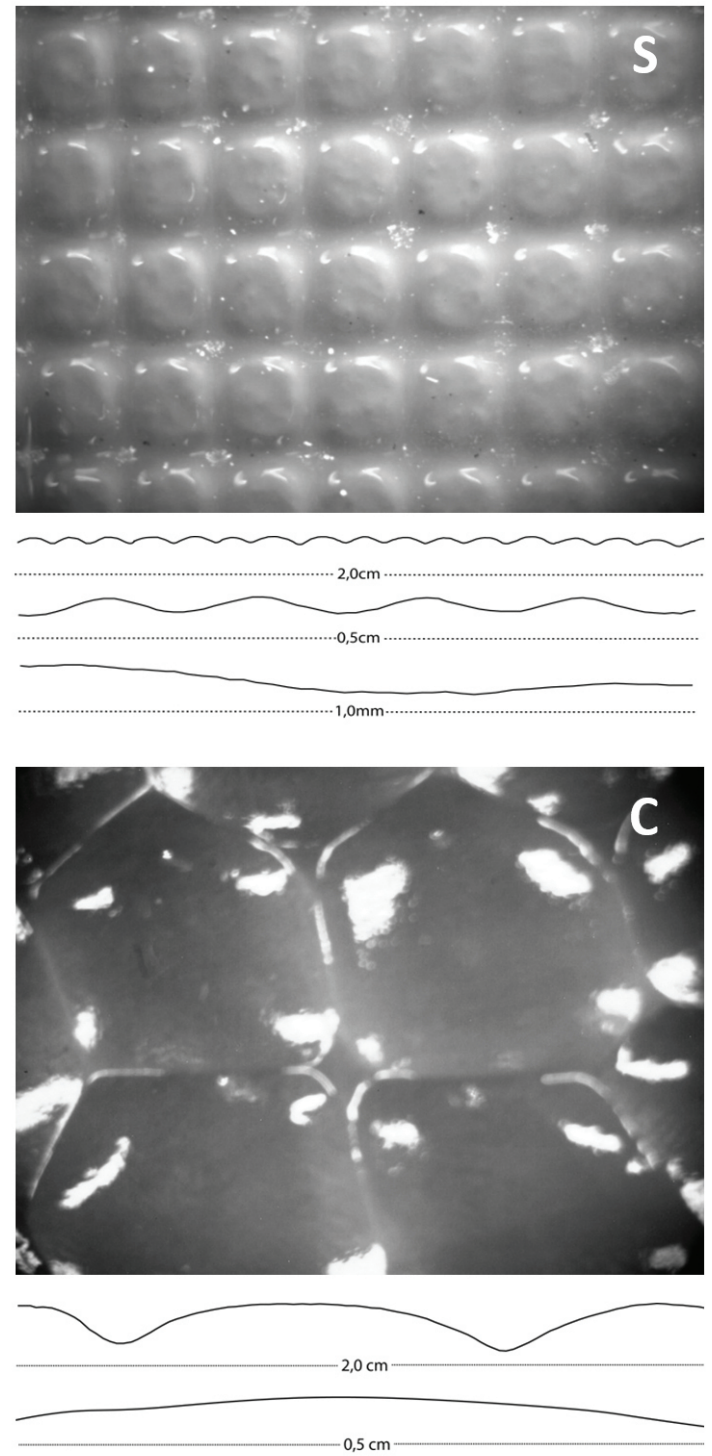

$-1,0 \mathrm{~mm}$

Figure 1. Photographs of the panoramic view of each surface and an illustration of the cross-section in three scales of observation $(2.0 \mathrm{~cm}, 0.5 \mathrm{~cm}$ and $1.0 \mathrm{~mm})$, except for the heterogeneity treatments where only $2.0 \mathrm{~cm}$ observation was taken. $\mathrm{P} ; \mathrm{S}, \mathrm{N}, \mathrm{C}, \mathrm{H} 1, \mathrm{H} 2$ and $\mathrm{H} 3$. 
The following environmental parameters were measured on the sampling occasion to characterize the streams: water temperature, $\mathrm{pH}$, dissolved oxygen, turbidity, specific conductance and current velocity. All parameter were measured using a Horiba U-10 equipped with multiparameter probe, except current velocity that was measured using a Swoffer 3000 flowmeter.

The quantification of macroalgal abundance in each substrate treatment was made in terms of percent cover of each species from digital images of the substrate surfaces, as describe by Tonetto et al. (2012a, b). For these quantitative analyses, the colonized glass plates were photographed in field with a Canon digital camera, Powershot A630, 8.0 megapixels. All photographs were taken with the camera $15 \mathrm{~cm}$ above the colonized glass plates. After this procedure, the images were analyzed using AutoCad software, version 2008, with the objective of quantifying the community and each macroalgal morphotype. For each photograph, each substratum area covered by a particular macroalgal morphotype was marked using a Bamboo digital multi-touch tablet with the help of the AutoCad selection tool. Following this, we used a specific function of the software (Area) to sum all marked areas covered by an individual macroalgal morphotype to measure its percent cover. This procedure was repeated for all macroalgal morphotype. To measure the percent cover of the macroalgal community as a whole, we summed the percentage cover of all individual macroalgal morphotypes in each photo. In order to calibrate the quantification method, we used the AutoCad scale function to establish the same scale for all images. This method allowed us to increase the measurement accuracy of abundance (in terms of percent cover) of the communities in relation to other methods commonly used in ecological studies involving these algae (Tonetto et al., 2012a)

For identifying the macroalgal species present on the artificial substrates, each macroalgal morphotype was examined in the laboratory with the help of a Leica DM 1000 microscope. After identification, the species were associated with its correspondent morphotype observed in the colonized plates.

Macroalgal percent cover during the experimental period was arcsine-square root transformed. The differences between surface types for percent cover of the individual species and the macroalgal communities were tested by a randomized block analysis of variance (ANOVA, using software Statistica version 7.0), with the 3 sites as blocks (DeNicola and Hoagland, 1996; Tonetto et al., 2012b). The randomized complete block design was adopted in order to control environmental heterogeneity (Sokal and Rohlf, 2000; Gotelli and Ellison, 2004). This is a type of two-way anova, usually without replicate, useful for biological studies (Sokal and Rohlf, 2000), which has been applied by a number of authors (Flecker and Townsend, 1994; Flecker et al., 2002; Usio and Townsend, 2004; Bechara et al., 2007; Landeiro et al., 2008), including for stream algal communities (DeNicola and Hoagland, 1996). This experimental design is considered efficient for highly variable environments such as streams, since the variation between blocks can be adjusted for differences in the treatments under comparison (Gotelli and Ellison, 2004).

\section{Results}

The physical and chemical characteristics of the water from the sampled streams were similar to those in other subtropical streams in Brazil (Branco et al., 2009) and were summarized in Table 1. Three macroalgal taxa were found colonizing the glass plates: Microcrocis sp. Richter (Cyanobacteria) was reported in all streams, while Tetraspora lubrica (Roth) C. Agardh (Chlorophyta) was found in streams A and B and, Stigeoclonium amoenum Kützing (Chlorophyta) was found in B and C. At the moment of the sampler installation we conducted a careful taxonomic survey on the natural substrates along the stream segments (ca. 20 meter length) where experiments were carried out. This analysis showed that the species attached on natural rocks was the same of those reported colonizing the artificial plaques in our experiment.

In general, the percent cover of macroalgal communities was low (less than 3\%) and had the highest mean value in the N surface type (2.8\%) (see Figure 2). For Microcrocis sp., the highest mean values were observed in the $\mathrm{N}(2.5 \%)$, H3 (2.3\%) and C (1.5\%) types, while S. amoenum displayed higher percent cover in $\mathrm{P}$ treatment (1.3\%), and T. lubrica showed a uniform occurrence among all types (see Figure 2). The analysis of variance did not reveal differences among surface shapes neither for macroalgae total abundance nor to each species individually (see Figure 2).

Despite the lack of significant differences among surfaces tested, all taxa were mainly found inside the crevices of the plates where they occurred. (see Figure 3).

Table 1. Physical and chemical features of water collected at the end day of experiment in each stream segments used on study.

\begin{tabular}{lcccccc}
\hline Streams & $\begin{array}{c}\text { Temperature } \\
\left({ }^{\circ} \mathbf{C}\right)\end{array}$ & $\mathbf{p H}$ & $\begin{array}{c}\text { Dissolved } \\
\text { Oxigen }(\mathbf{m g} \\
\left.\mathbf{L}^{-\mathbf{1}}\right)\end{array}$ & $\begin{array}{c}\text { Conductivity } \\
\left(\boldsymbol{\mu} \mathbf{S} \mathbf{~ c m}^{-1}\right)\end{array}$ & $\begin{array}{c}\text { Turbidity } \\
(\mathbf{N T U})\end{array}$ & $\begin{array}{c}\text { Current speed } \\
\left(\mathbf{c m . s}^{-1}\right)\end{array}$ \\
\hline $\mathrm{A}$ & 12.8 & 6.92 & 10.0 & 34 & 42 & 72.9 \\
$\mathrm{~B}$ & 13.1 & 7.03 & 9.89 & 30 & 68 & 80.2 \\
$\mathrm{C}$ & 11.8 & 6.60 & 10.23 & 31 & 58 & 74.6 \\
Mean & $12.5 \pm 0.5$ & $6.8 \pm 0.2$ & $10.0 \pm 0.1$ & $31.6 \pm 1.7$ & $56.0 \pm 10.7$ & $75.9 \pm 3.1$ \\
\hline
\end{tabular}




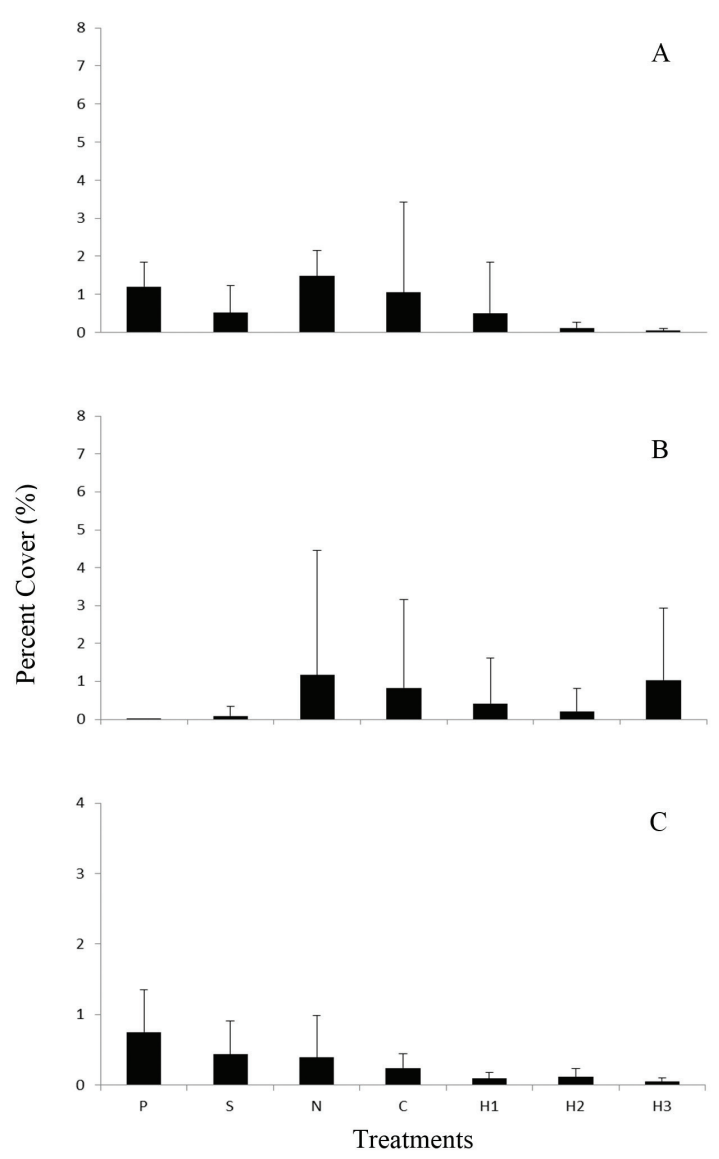

Figure 2. Percent cover values in each treatment for the entire community of macroalgae (A), Microcrocis sp. (B) and Tetraspora lubrica + Stigeoclonium amoenum (C).

\section{Discussion}

The mean values of percent cover observed in all surfaces were low, and this characteristic has been described as typical for macroalgal communities and several studies have already reported this response (Krupek et al., 2007; Branco et al., 2009; Tonetto et al., 2012b).

The treatments with different crevice sizes showed no significant influence on the establishment of macroalgal communities and species individually. Although the surface types were different in relation to crevice size, the dimension used in the present study was probably not enough to provide differences in macroalgal growth. Actually, as showed by Figure 1, at small scale, all treatments had a smooth surface and this characteristic may have influenced more strongly the macroalgal establishment than differences in amount and size of crevices of the surfaces tested, at the dimension used. Thus, our results corroborate previous studies, which reported that the smooth surfaces accumulate low abundance of algae (Dudley and D'Antonio, 1991; Downes et al., 1998; Murdock and Dodds, 2007).

Despite the low abundance recorded in all treatments, we observed an evident predominance of algae inside crevices. Similar observations was previously described, even in

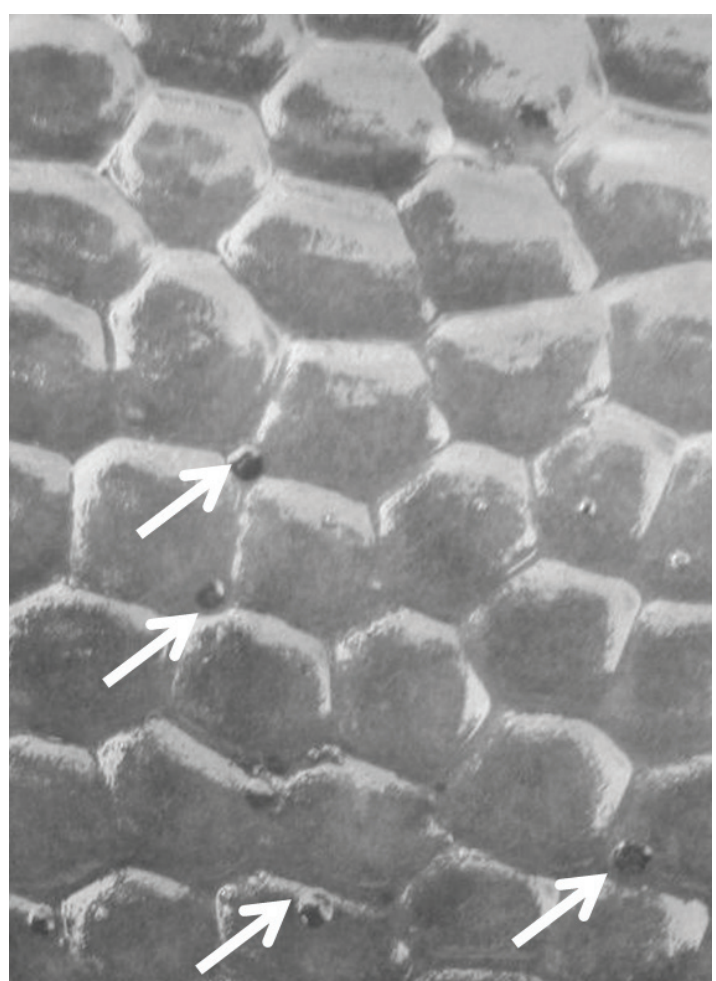

Figure 3. Illustrative example for T. lubrica attached within the crevices.

smooth surfaces (Dudley and D'Antonio, 1991), which is similar with our observations. Probably, the deposition of algae within the crevices is due to the accumulation of debris in them and the possible establishment of refuges (Bergey, 1999; Nowell and Jumars, 1984; Davis and Barmuta, 1989; Snelgrove et al., 1993). In the present study we tested surfaces with crevice sizes greater than previous studies (with periphytic community) considering that macroalgae would require larger crevices to get refuge, as reported for larger diatoms (Bergey, 1999). Actually, we found macroalgae within the crevices, but the shapes and dimensions used seemed to be insufficient and then limiting the growth of these organisms. Indeed, for crevices to be effective refuges, organisms must not only fit within it, but also be located in disturbance-protected parts of crevices (Bergey and Weaver, 2004).

In conclusion, the results of this study suggest that crevices on substrate surfaces could influence the macroalgal community colonization; however, the lack of significant differences among treatments could be due to the size and shape of experimental crevices that may have exposed the macroalgae to some damage effects, such as herbivory activity and/or abrasive action of water flow. There may be an influence of the treatments scale used in this work, but it was not strong enough to appear in the analysis. If there is, this scale is part of the complexity of the environment as an element of its architecture and can hardly be isolated from the influences of other scales. 
Therefore, we recommend further studies on the influence of surface types on macroalgae species at larger scales, since such information could reveal additional relevant relationships between stream macroalgae and physical features of the substrate.

\section{Acknowledgments}

This research was supported by a FAPESP grant-in-aid (Proc. 07/52608-1) and a research grant to AFT (2010/17563-0), by a CNPq research grant to CCZB (Proc. 302354/2008-5) and by a CAPES research grant to CKP (141754/2007-9). The help in fieldworks by Bruno P. Crulhas and Gustavo H. Jerônimo and the critical comments on the manuscript by Ricardo C. Leite are gratefully acknowledged.

\section{References}

BECHARA, JA., PLANAS, D. and PAQUET, S., 2007. Indirect effects of brook trout (Salvelinus fontinalis) on the structure of epilithic algal communities in an oligotrophic boreal forest stream. Fundamental and Applied Limnology, vol. 169, no. 2, p. 89-99. http://dx.doi.org/10.1127/1863-9135/2007/0169-0089.

BERGEY, EA., 1999. Crevices as refugia for stream diatoms: Effects of crevice size on abraded substrates. Limnology and Oceanography, vol. 44, no. 6, p. 1522-1529. http://dx.doi. org/10.4319/1o.1999.44.6.1522.

BERGEY, EA. and WEAVER, J., 2004. The influence of crevice size on the protection of epilithic algae from grazers. Freshwater Biology, vol. 49, no. 8, p. 1014-1025. http://dx.doi.org/10.1111/ j.1365-2427.2004.01245.x.

BRANCO, CCZ., KRUPEK, RA. and PERES, CK., 2009. Distribution of stream macroalgal communities from the mid-western region of Paraná State, southern Brazil: Importance of local scale variation. Fundamental and Applied Limnology, vol. 52, no. 2, p. 379-386. http://dx.doi.org/10.1590/S1516-89132009000200015.

BRANCO, CCZ., NECCHI JUNIOR, O. and PERES, CK., 2010. Effects of artificial substratum types and exposure time on macroalgal colonization ina tropical stream. Fundamental and Applied Limnology, vol. 178, no. 1, p. 17-27. http://dx.doi. org/10.1127/1863-9135/2010/0178-0017.

DAVIS, JA. and BARMUTA, LA., 1989. An ecologically useful classification of mean and near-bed flows in streams and rivers. Freshwater Biology, vol. 21, no. 2, p. 271-282. http://dx.doi. org/10.1111/j.1365-2427.1989.tb01365.x.

DENICOLA, DM. and HOAGLAND, KD., 1996. Effects of Solar Spectral Irradiance (Visible to UV) on a Prairie Stream Epilithic Community. Journal of the North American Benthological Society, vol. 15, no. 2, p. 155-169. http://dx.doi.org/10.2307/1467945.

DOWNES, BJ., LAKE, PS., SCHREIBER, ESG. and GLAISTER, A., 1998. Habitat structure and regulation of local species diversity in a stony, upland stream. Ecological Monographs, vol. 68, no. 2, p. 237-257. http://dx.doi.org/10.1890/0012-9615(1998)068[0237:HS AROL]2.0.CO;2.

DUDLEY, TL. and D'ANTONIO, CM., 1991. The effects of surface texture, grazing, and disturbance on macroalgal establishment in streams. Ecology, vol. 72, no. 1, p. 297-304. http://dx.doi. org/10.2307/1938923.
EVERITT, DT. and BURKHOLDER, JM., 1991. Seasonal dynamics of macrophyte communities from a stream flowing over granite flatrock in North Carolina, USA. Hydrobiologia, vol. 222, no. 3, p. 159-172. http://dx.doi.org/10.1007/BF00016155.

FLECKER, AS. and TOWNSEND, CR., 1994. Community-wide consequences of trout introduction in New Zealand streams. Ecological Applications, vol. 4, no. 4, p. 798-807. http://dx.doi. org/10.2307/1942009.

FLECKER, AS., TAYLOR, BW., BERNHARDT, ES., HOOD, JM., CORNWELL, WK., CASSATT, SR., VANNI, MJ. and ALTMAN, NS., 2002. Interactions between herbivorous fishes and limiting nutrients in a tropical stream ecosystem. Ecology, vol. 83, no. 7, p. 1831-1844. http://dx.doi.org/10.1890/00129658(2002)083[1831:IBHFAL]2.0.CO;2.

GOTELLI, NJ. and ELLISON, AM., 2004. A primer of ecological statistics. Massachusetts: Sinauer Associates Publishers. 510 p.

JOHNSON, LE., 1994. Enhanced settlement on microtopographical high points by the intertidal red alga Hallosaccion glandiforme. Limnology and Oceanography, vol. 39, no. 8, p. 1893-1902. http://dx.doi.org/10.4319/lo.1994.39.8.1893.

KRUPEK, RA., BRANCO, CCZ. and PERES, CK., 2007. Distribuição ecológica das comunidades de macroalgas da bacia de drenagem do Rio das Pedras, região Centro-Sul do estado do Paraná, sul do Brasil. Brazilian Journal of Botany, vol. 30, no. 2, p. 173-182. http://dx.doi.org/10.1590/S0100-84042007000200002.

KRUPEK, RA., BRANCO, CCZ. and PERES, CK., 2008. Levantamento florístico das comunidades de macroalgas da bacia do Rio das Pedras, região centro-sul do Estado do Paraná, Sul do Brasil. Hoehnea, vol. 35, no. 2, p. 189-208. http://dx.doi. org/10.1590/S2236-89062008000200003.

LANDEIRO, VL., HAMADA, N. and MELO, AD., 2008. Responses of aquatic invertebrate assemblages and leaf breakdown to macroconsumer exclusion in Amazonian "terra firme" streams. Fundamental and Applied Limnology, vol. 172, no. 1, p. 49-58. http://dx.doi.org/10.1127/1863-9135/2008/0172-0049.

MURDOCK, JN. and DODDS, WK., 2007. Linking benthic algal biomass to stream substratum topography. Journal of Phycology, vol. 43, no. 3, p. 449-460. http://dx.doi.org/10.1111/j.15298817.2007.00357.x.

NOWELL, ARM. and JUMARS, PA., 1984. Flow environments of aquatic benthos. Annual Review of Ecology and Systematics, vol. 15 , no. 1, p. 303-328. http://dx.doi.org/10.1146/annurev. es.15.110184.001511

PERES, CK., BRANCO, CCZ. and KRUPEK, RA., 2009. Distribuição ambiental e temporal das comunidades de macroalgas de riachos da Serra da Prata, Estado do Paraná, Sul do Brasil. Brazilian Journal of Botany, vol. 32, no. 4, p. 625-633. http:// dx.doi.org/10.1590/S0100-84042009000400002.

POFF, NL. and WARD, JV., 1990. Physical habitat template of lotic systems: Recovery in the context of historical pattern of spatiotemporal heterogeneity. Environmental Management, vol. 14, no. 5, p. 629-645. http://dx.doi.org/10.1007/BF02394714.

ROSEMOND, AD. and BRAWLEY, SH., 1996. Species-specific characteristics explain the persistence of Stigeoclonium tenue (Chlorophyta) in a woodland stream. Journal of Phycology, vol. 28, p. $109-118$.

SCARDINO, AJ., HARVEY, E. and DE NYS, R., 2006. Testing attachment point theory: diatom attachment on microtextured 
polyimide biomimics. Biofouling, vol. 22, no. 1-2, p. 55-60. http://dx.doi.org/10.1080/08927010500506094. PMid:16551561

SHEATH, RG. and COLE, KM., 1992. Biogeography of stream macroalgal in North America. Journal of Phycology, vol. 28, no. 4, p. 448-460. http://dx.doi.org/10.1111/j.0022-3646.1992.00448.x.

SHEATH, RG., HAMILTON, PB., HAMBROOK, JA. and COLE, KM., 1989. Stream macroalgae of eastern boreal forest region of North America. Canadian Journal of Botany, vol. 67, no. 12, p. 3553-3562. http://dx.doi.org/10.1139/b89-437.

SNELGROVE, PVR., BUTMAN, CA. and GRASSLE, JP., 1993. Hydrodynamic enhancement of larval settlement in the bivalve Mulinia laterals (Say) and the polychaete Capitella sp. I in microdepositional environments. Journal of Experimental Marine Biology and Ecology, vol. 168, no. 1, p. 71-109. http:// dx.doi.org/10.1016/0022-0981(93)90117-7.

SOKAL, RR. and ROHLF, FJ., 2000. Biometry. New York: W. H. Freeman and Company. $887 \mathrm{p}$.
TONETTO, AF., PERES, CK. and BRANCO, CCZ., 2012a. A new method to quantify macroalgae and a practical sampler for experimentation in lotic habitats. Revista Brasileira de Biologia = Brazilian Journal of Biology, vol. 72, no. 4, p. 853-857.http:// dx.doi.org/10.1590/S1519-69842012000500011. PMid:23295514

TONETTO, AF., BRANCO, CCZ. and PERES, CK., 2012b. The effects of irradiance and spectral composition on the establishment of macroalgae in streams in southern Brazil. Annales de Limnologie: International Journal of Limnology, vol. 48, no. 4, p. 363-370. http://dx.doi.org/10.1051/limn/2012027.

TOWNSEND, CR. and HILDREW, AG., 1994. Species traits in relation to a habitat templet for river systems. Freshwater Biology, vol. 31, no. 3, p. 265-275. http://dx.doi.org/10.1111/j.1365-2427.1994. tb01740.x

USIO, N. and TOWNSEND, C., 2004. Roles of crayfish: consequences of predation and bioturbation for stream invertebrates. Ecology, vol. 85, no. 3, p. 807-822. http://dx.doi.org/10.1890/02-0618. 